\title{
Concern over Zika virus outbreak: another alarming global threat
}

Muhammad Yusuf Hafiz'

Syed Uzair Mahmood ${ }^{2}$

Maria Shoaib'

Farah Hafiz Yusuf'

'Dow Medical College, Dow University of Health Sciences, ${ }^{2}$ Sindh Medical College, Jinnah Sindh Medical University, Karachi, Pakistan
This article was published in the following Dove Press journal:

Infection and Drug Resistance

28 June 2016

Number of times this article has been viewed

\begin{abstract}
Zika virus, as highlighted by the World Health Organization in February 2016, has emerged as a public health emergency of international concern. Zika virus is enveloped and icosahedral, and has a nonsegmented, single-stranded, positive-sense RNA genome. It belongs to Flaviviridae family. Aedes aegypticus mosquito is the known vector. Transmission is anthroponotic (human to vector to human) during outbreaks, or occurs perinatally in utero, sexually, and via transfusion of infected blood. Zika virus is turning out to be a major public health concern. Not only has it shown dramatic teratogenic association and caused serious neurological concerns but it has also spread around the globe. Countries that have not yet been affected by Zika virus should adopt proper preventive methods to limit its spread in
\end{abstract} the population.

Keywords: Zika virus, global spread, teratogenic, neurological anomalies, public health emergency

\section{Introduction}

Zika virus, as highlighted by the World Health Organization in February 2016, has emerged as a public health emergency of international concern. The virus appeared less benign than initially thought but has dramatically become a global threat that embarks health risk to many countries. It has showed not only unexpected congenital birth defects but also serious neurological manifestations which emphasize on its awareness, prevention, and eradication in a coordinated way. Hence, immediate actions should be taken in the affected region. It has established temporal association with clusters of microcephaly cases and serious motor neuron-paralyzing diseases in Latin America and Brazil, and has also been documented in French Polynesia retrospectively which has alarmed the Health Regulation Emergency Committee. ${ }^{1,2}$

\section{Background and identification}

Zika virus was initially identified in serum of a pyrexial rhesus monkey in 1947, in a caged canopy of Zika Forest. Hence, the virus has been named Zika virus referring to the locality from where it was isolated first. ${ }^{3}$ Its subsequent spread to humans has been sporadically noted as an anthroponotic infection. In 2007, the first documented outbreak of Zika occurred in the Federal States of Micronesia where 185 suspected cases were reported, of which 49 were confirmed and 59 were considered probable. Between 2013 and 2014, four additional Pacific Island nations documented large Zika
Correspondence: Muhammad Yusuf Hafiz 246 CP Berar Society, Flat No 8, 2nd floor, Karachi 75600, Pakistan Email m.yusufhafiz17@gmail.com 
outbreaks. From South America and Brazil, however, it has become endemic to many parts of the world, including Africa, Asia, and Pacific Island countries. ${ }^{4,5}$

\section{Zika's virology and vector}

Zika virus is enveloped and icosahedral, and has a nonsegmented, single-stranded, positive-sense RNA genome. It is most closely related to the Spondweni virus, with which it forms a clade within the Flaviviridae family. It is known to transmit to humans primarily through the bite of an infected Aedes sp. mosquito, which is also known to carry dengue, chikungunya, and yellow fever virus.

Aedes aegypticus are the commonly found mosquitoes in tropics and subtropical areas. They preferentially feed on human blood and can insensibly bite several people in a short span for one blood meal. They breed in domestic water-holding containers such as cans, pots, and buckets. They are aggressive daytime feeders and are known to bite from dawn to dark. ${ }^{6}$ Nonhuman and human primates are likely the main reservoirs of the virus. Transmission is anthroponotic (human to vector to human) during outbreaks, or occurs perinatally in utero and via transfusion of infected blood. ${ }^{4}$ Moreover, Zika virus can be transmitted sexually. The virus can persist in the semen for a longer period as compared to blood. ${ }^{7}$

\section{Symptoms and clinical presentation}

The infection presents as a typical viral, mild and self-limiting disease, symptomatic in $20 \%$ of individuals, and generally has an incubation period of few days. It appears clinically as mild headache, maculopapular rash, low-grade fever, malaise, conjunctivitis, lymphadenopathy, and joint pain. Such atypical symptoms often hinder a definite differential diagnosis unlike other viral infections. Fortunately, severe disease requiring hospitalization is uncommon, and case fatality is low. Serious manifestations of Zika virus include Guillain-Barre syndrome and congenital birth defects, and these are raising great concern. ${ }^{8,9}$

\section{Zika and its teratogenic association}

Microcephaly is a condition of neurological and congenital birth anomaly in which an infant's head is significantly smaller than the heads of other children of the same age and sex; this corresponds to serious mental and growth retardation syndromes. During October and November 2015, the Ministry of Health in Brazil began reporting an unusual increase in cases of microcephaly, first in the state of Pernambuco, located in the northeast of Brazil, and then in three other states. It was declared that the situation is of national public health emergency, and they began undertaking clinical, laboratory, and ultrasound analysis of affected newborn babies and their mothers.

The WHO and Pan American Health Organization issued an epidemiological alert. Due to these concerns, fetuses and infants of women infected with Zika virus during any trimester of pregnancy were evaluated, and a link of infectivity was established. ${ }^{8}$ Zika virus RNA can be detected with reverse transcriptase-polymerase chain reaction (RT-PCR) in body fluids of the mother and in the amniotic fluid of pregnant women who were suspected for Zika virus infection, indicating transplacental transmission. It is a mild infection, but during pregnancy, it appears to be associated with grave outcomes, which include fetal death, placental insufficiency, fetal growth restriction, and central nervous system anomalies (microcephaly and/or ventricular calcifications or other lesions). ${ }^{10,11}$

\section{Diagnosis and treatment}

Diagnosis of Zika virus infection is based on physician's judgment of clinical symptoms and patient's history. Laboratory test including RT-PCR of body fluids can be a suggestive definite diagnosis. Virus-specific IgM and neutralizing antibodies develop toward the end of the initial week of illness because of cross reactivity with related flaviviruses; the IgM antibodies are not much of a determinant marker.

Supportive treatment is offered, including rest, intravenous fluids and hydration, and use of analgesics and antipyretics for symptoms. Aspirin and other nonsteroidal anti-inflammatory drugs should be avoided. ${ }^{8}$

\section{Prevention and recommendation}

As it is a vector-borne disease, infected people should be isolated as precaution to reduce the risk of transmission. The WHO has emphasized on preventive guidelines, which include insect repellants, wearing fully covered clothes for physical barriers, sleeping under mosquito nets, and avoiding indoor water containers. Vector control can be achieved by eradicating breeding sites. Endemic countries have been declared unsafe to travel, particularly for pregnant women. Safe traveling plans should be made consulting physicians beforehand and on returning from the endemic areas. A few agencies have also suggested Zika Quarantine for this sake. Currently, no specific antiviral treatment or vaccination is available for Zika virus infection, although it is one great breakthrough awaited; till then, prevention and precaution is the need of time. ${ }^{11-13}$ 


\section{Conclusion}

Zika virus is turning out to be a major public health concern. Not only has it shown dramatic teratogenic association and caused serious neurological concerns but it has also spread around the globe as an arbovirus threat. ${ }^{14,15}$ Countries that have not yet precipitated Zika virus should take adopt preventive methods such as vector control, ensure safe traveling, and provide public education to take self-precautionary measures to keep themselves protected from the vector mosquito or the virus spreading via contact, transplacentally, or sexually. Government and authorities are advised to take their roles in limiting its spread in the population by taking adequate steps in the line of precaution and eradication. ${ }^{16}$

\section{Disclosure}

The authors report no conflicts of interest in this work.

\section{References}

1. Heymann DL, Hodgson A, Sall AA, et al. Zika virus and microcephaly: why is this situation a PHEIC? Lancet. 2016;387(10020):719.

2. Samarasekera U, Triunfol M. Concern over Zika virus grips the world. Lancet. 2016;387(10018):521-524.

3. Dick GW, Kitchen SF, Haddow AJ. Zika virus (I). Isolations and serological specificity. Trans R Soc Trop Med Hyg. 1952;46(5):509-520.

4. Musso D, Nilles EJ, Cao-Lormeau VM. Rapid spread of emerging Zika virus in the Pacific area. Clin Microbiol Infect. 2014;20(10):O595-O596.
5. Duffy MR, Chen TH, Hancock WT, et al. Zika virus outbreak on Yap Island, federated states of Micronesia. $N$ Engl J Med. 2009;360(24):2536-2543.

6. Wilder-Smith A, Schwartz E. Dengue in travelers. $N$ Engl J Med 2005;353(9):924-932.

7. Centers for Disease Control and Prevention. Zika virus. Zika and sexual transmission. Available from: http://www.cdc.gov/zika/transmission/ sexual-transmission.html. Accessed March 8, 2016.

8. Zammarchi L, Stella G, Mantella A, et al. Zika virus infections imported to Italy: clinical, immunological and virological findings, and public health implications. J Clin Virol. 2015;63:32-35.

9. Talan J. Epidemiologists are tracking possible links between Zika virus, microcephaly, and Guillain-Barré syndrome. Neurol Today. 2016;16(4):1-8.

10. Dyer O. Zika virus spreads across Americas as concerns mount over birth defects. BMJ. 2015;351:h6983.

11. Calvet G, Aguiar RS, Melo AS, et al. Detection and sequencing of Zika virus from amniotic fluid of fetuses with microcephaly in Brazil: a case study. Lancet Infect Dis. Epub 2016 Feb 17.

12. European Centre for Disease Control and Prevention. Factsheet for health professionals. Available from: http://ecdc.europa.eu/en/healthtopics/zika_virus_infection/factsheet-health-professionals/Pages/ factsheet_health_professionals.aspx. Accessed March 8, 2016.

13. Goorhuis A, von Eije KJ, Douma RA, et al. Zika virus and the risk of imported infection in returned travelers: implications for clinical care. Travel Med Infect Dis. 2016;14(1):13-15.

14. Adibi JJ, Marques ET, Cartus A, Beigi RH. Teratogenic effects of the Zika virus and the role of the placenta. Lancet. 2016;387(10027):1587-1590.

15. Paixão ES, Barreto F, da Glória Teixeira M, da Conceição N, Costa M, Rodrigues LC. History, epidemiology, and clinical manifestations of Zika: a systematic review. Am J Public Health. 2016;106(4):606-612.

16. Centers for Disease Control and Prevention. Zika virus. Prevention. Available from: http://www.cdc.gov/zika/prevention/. Accessed March 8, 2016.
Infection and Drug Resistance

\section{Publish your work in this journal}

Infection and Drug Resistance is an international, peer-reviewed openaccess journal that focuses on the optimal treatment of infection (bacterial, fungal and viral) and the development and institution of preventive strategies to minimize the development and spread of resistance. The journal is specifically concerned with the epidemiology of antibiotic

\section{Dovepress}

resistance and the mechanisms of resistance development and diffusion in both hospitals and the community. The manuscript management system is completely online and includes a very quick and fair peerreview system, which is all easy to use. Visit http://www.dovepress.com/ testimonials.php to read real quotes from published authors. 